\title{
Land suitability for final waste disposal with emphasis on septic systems installation in southern Minas Gerais, Brazil
}

\author{
Aptidão das terras para a destinação final de resíduos com destaque \\ para a instalação de fossas sépticas no sul de Minas Gerais, Brasil
}

\author{
Jeani Moreira de Oliveira ${ }^{1 *}$, Sérgio Henrique Godinho Silva ${ }^{1}$, Michele Duarte de Menezes², $^{2}$ \\ Nestor Kämpf ${ }^{3}$, Nilton Curi
}

\author{
${ }^{1}$ Universidade Federal de Lavras/UFLA, Lavras, MG, Brasil \\ 2Universidade Federal de Lavras/UFLA, Departamento de Ciência do Solo/DCS, Lavras, MG, Brasil \\ 3Universidade Federal do Rio Grande do Sul/UFRS, Departamento de Solos, Porto Alegre, RS, Brasil \\ *Corresponding author: jeanimoreira@yahoo.com.br \\ Received in june 26, 2015 and approved in september 21, 2015
}

\begin{abstract}
Environmental pollution is a problem that has been noted due to changes in the environment, affecting natural resources. Regarding the soil, it may offer great potential for waste disposal. Thus, this study aims to propose criteria for evaluating local suitability for waste disposal, according to soil and terrain attributes for southern Minas Gerais State, and to apply those criteria to define the most appropriate locations for installation of septic systems in a pilot watershed. Literature and the authors' experience were used to propose the more important criteria regarding the suitability of sites for waste disposal. The set of attributes taken into account was grouped into four suitability classes: Adequate, Regular, Restricted and Inadequate. The defined criteria and considered limiting were: soil depth, texture, textural gradient, structure, natural drainage, water infiltration, type of surface horizon, water table depth, depth of perched water table, distance from water bodies, relief, stoniness, rockiness and risk of flooding. From these, soil depth, natural drainage, water table depth, relief and distance from water bodies were adopted for the installation of septic systems. From the total area of the watershed, $5.29 \%$ fit in the Adequate suitability class. The Regular, Restricted, and Inadequate sites accounted for, respectively, $19.72 \%, 41.99 \%$ and $33 \%$ of the wathershed. Factors such as soil and terrain attributes provide a basis for defining more appropriate places for waste disposal. Future work should involve the refinement of these propositions, since there are rare studies in this research line in Brazil.
\end{abstract}

Index terms: Environmental pollution; watershed; pedology.

\section{RESUMO}

A poluição ambiental é um grande problema que tem sido notado em decorrência das alterações que ocorrem no ambiente, afetando os recursos naturais. Em relação ao solo, este oferece grande potencial para a destinação final de resíduos. Nesse sentido, objetivou-se, neste trabalho, propor critérios para avaliar a aptidão de locais para a destinação final de resíduos, de acordo com atributos do solo e do terreno, para o sul do Estado de Minas Gerais, e aplicar esses critérios para definir os locais mais apropriados para a instalação de sistemas de fossas sépticas, seguidas de vala de infiltração, em uma sub-bacia hidrográfica piloto. Foram utilizados dados da literatura e a experiência dos autores para a proposição de critérios mais importantes no tocante à aptidão dos locais para a destinação final de resíduos. O conjunto de atributos considerados foi agrupado em quatro classes de aptidão: Adequada, Regular, Restrita e Inadequada. Os critérios definidos e considerados limitantes foram: profundidade do solo, textura, gradiente textural, estrutura, drenagem natural, infiltração de água, tipo de horizonte superficial, profundidade do lençol freático, profundidade do lençol suspenso, distância do curso hídrico, relevo, pedregosidade, rochosidade e risco de inundação. Destes, foram adotados a profundidade do solo, drenagem natural, profundidade do lençol freático, relevo e distância do curso hídrico para a instalação de fossas sépticas. Da área total da sub-bacia, 5,29\% se enquadraram na classe de aptidão Adequada. Os locais de aptidão Regular, Restrita e Inadequada totalizaram respectivamente 19,72\%, $41,99 \%$ e 33\% da área da sub-bacia. Fatores como atributos do solo e do terreno dão subsídios para a definição de locais mais propensos à destinação final de resíduos. Trabalhos futuros nessa linha de pesquisa deveriam envolver o refinamento dessas proposições, uma vez que há raros estudos dessa natureza no Brasil.

Termos para indexação: Poluição ambiental; sub-bacia hidrográfica; pedologia.

\section{INTRODUCTION}

Environmental pollution is a major problem that has been noted due to changes occurring in the environment, being them natural or anthropic, and that directly affect the lives of human and animal beings. The environment consists of the interaction between living beings, water, atmosphere and land, and any changes in one of these 
factors can trigger positive or negative consequences in the others. In relation to the soil, in addition to its importance for food production, it offers great potential as a means of disposal or recycling wastes due to its capacity to promote the modification of organic and inorganic compounds by means of chemical reactions, physical or biological processes. Furthermore, it functions as a filter, decreasing the residue contamination and preventing many pollutants to get in contact with groundwater.

Soil pollution can be understood as the presence of substances that negatively alter its quality, and may be the cause of public health problems resulting from the indiscriminate disposal of liquid or solid waste on soil, which can cause contamination of the water table and increase the speed of the contamination front. The domestic and industrial wastes are the main responsible for pollution of hydric bodies, especially for the Brazilian medium and large cities. According to Von Sperling (1996), the ecosystem of a soil body prior to waste disposal is usually in a balanced stage, thus, the release of in natura domestic sewage and wastewater may cause proliferation of pathogenic microorganisms not only to humans, but also to local fauna and pets. The release of untreated domestic wastewater is a problem that affects both urban and rural areas. In the latter, sanitation is almost inexistent in most Brazilian regions. A way to minimize this type of problem is the installation of septic tanks followed by drain field systems.

According to Instituto Brasileiro de Geografia e Estatística-IBGE (2012), in Brazil only 5.2\% of the rural properties have sewage connected to the sewage network and $28.3 \%$ contain septic systems (connected or not connected to the network). Furthermore, inappropriate solutions are commonly adopted, including rudimentary septic systems and other alternatives, such as disposal of waste water directly from the house plumbing on the soil surface, and direct disposal of residues on water courses, that can be found in $45.3 \%$ and $7.7 \%$ of those properties, respectively, although this scenary is relatively better than the observed in $13.6 \%$ of them, which do not adopt any solution at all. On the other hand, in urban areas $65.5 \%$ of the properties have access to sewage network. Septic systems have the function to separate and transform the solid matter contained in the waste water, while the drain field is installed for depuration and final disposal of sewage in the subsurface soil, containing distribution piping and filtration means therein. It is recommended that the installed system distributes relatively small amounts of effluent in a non-concentrated form to avoid clogging of the soil and the poor purification of the effluent.
For Bouma (1979), an acceptable performance of any treatment and disposal systems for domestic liquid waste implies on the liquid infiltration into the soil followed by its transformation during percolation, so that it does not contaminate the surface and subsurface water. In this context, the factors that offer great risk to the environment and human health are resulted from the movement of components deposited in the septic tank, causing contamination of surface and subsurface waters. Therefore, septic tanks can be an alternative to improve the disposal of waste in the countryside (mostly), improving sanitation and protecting the water table. However, it is necessary to consider the soil classes (and their properties) of the available areas in order to better allocate septic tanks, since different soils tend to present variable suitability to receive residues without damaging the environment.

In this sense, the aims of this study are to propose criteria for evaluating local suitability for the final disposal of waste, according to soil and terrain attributes, for southern Minas Gerais State, and to apply those criteria for the installation of septic tanks followed by drain fields in a pilot watershed. We focused on the importance of soil as a receiver and absorber of effluents, also taking into account the topographic variables, therefore engineering aspects for the construction of this type of system was not contemplated herein (Associação Brasileira de Normas Técnicas-Abnt, 1993).

\section{MATERIAL AND METHODS}

For the definition of the most appropriate places for waste disposal in southern Minas Gerais region, criteria that represent attributes of the soil and terrain features were considered limiting to this purpose, being selected based on the literature and on the authors' experience. These factors were interpreted to allow an overall rating of resistance of these locales against environmental impacts caused by the disposal of waste, since some types of impacts may require the use of specific criteria and further evaluation.

The soil and the terrain features accounted for assessing the land suitability for disposal of waste were grouped in four suitability classes, represented by the terms Adequate, Regular, Restricted and Inadequate. The Adequate class combines the best conditions for the disposal of waste, while the others show, respectively, increasing restrictions in this regard. A land is classified as Regular, Restricted or Inadequate when it presents at least one limiting factor with regard to the most appropriate condition.

It was developed a guide table of the suitability classes for the final disposal of waste, which presents the criteria for land classification in their suitability classes. 
In this context, the most limiting factor is considered as the one that determines the suitability class.

As a case study, based on the guide table, soil properties and terrain features considered relevant for the definition of more suitable locales for installation of septic tanks and drain fields were selected in order to promote an efficient absorption and purification of effluents. These factors were applied to Marcela Creek watershed, located in Nazareno county, state of Minas Gerais, Brazil (Figure 1), which has great environmental importance and supplies water for the hydroelectric power plant of Itutinga/Camargos, with altitudes ranging from 960 to 1060 meters, covering 485.71 ha.

The soils occurring in the study area (Motta et al. 2001) according to the Brazilian Soil Classification System (Empresa Brasileira de Pesquisa Agropecuária-Embrapa, 2013) (Figure 1) are: Dystrophic Red-Yellow Latosol (RYL) with moderate A horizon, very clayey texture, covering 325.23 ha, corresponding to $66.96 \%$ of the total area of the sub-basin; Dystrophic Red Latosol (RL) with moderate A horizon, very clayey texture, occupying 63.87 ha (13.15\%); Tb Haplic Cambisol (HC), moderate A horizon, very clayey texture, which has an area of 21.28 ha $(4.38 \%)$; and Dystrophic Haplic Gleysol (HG) with moderate A horizon, very clayey texture, occupying 75.33 ha, or $15.51 \%$ of the area. Based on the soil map (Motta et al., 2001), topographic information and the authors' experience, it was generated a map of the suitability of each location for installing septic systems (Figure 2), using ArcGIS 10.1 (ESRI) software, in order to identify the sites and quantify the geographical expression of the most suitable or less suitable areas for such installation. A digital elevation model (DEM) with spatial resolution of $10 \mathrm{~m}$ derived from contour lines at a scale of 1:50,000 (IBGE) was employed to create the slope gradient map, which was used as a source of topographic information for assessing the suitability of each local on the study area.

\section{RESULTS AND DISCUSSION}

\section{Sustainability classes for final waste disposal}

The basis and the interpretation of factors presented below were essential to direct the suitability of sites for the disposal of waste Kämpf et al. (2008):

- Soil depth: influences on soil volume available for absorption and attenuation effects. Silva et al. (2010) found an efficient degradation of contaminants in deeper soil layers due to the increased amount of clay in depth. Bitton (1994) noted that in layers deeper than $3 \mathrm{~m}$ in the soil profile, fecal coliforms present in wastewater cannot survive, probably due to the lack of organic material, which has fundamental importance for their survival.

- Texture: the clay fraction is essential to the sorption, retention and buffering of impacting materials (Streck et al., 2008).

- Mineralogy: Latosols and Nitosols, depending on the predominance of kaolinite or $\mathrm{Fe}$ and $\mathrm{Al}$ oxides

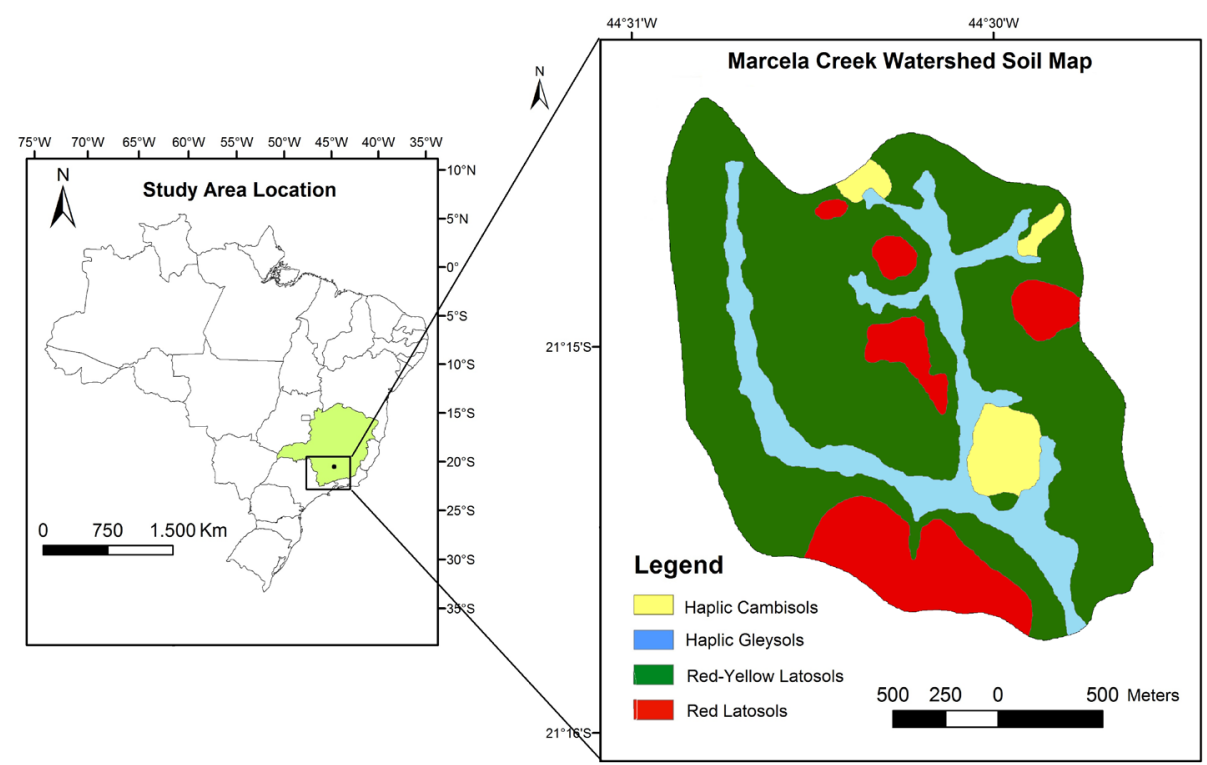

Figure 1: Marcela Creek watershed location and its soil map adapted from Motta et al. (2001). 
(Resende et al., 2011), are prioritized for conditioning greater soil physical stability (easier management of the soil, improved trafficability etc.). However, Vertisols, with a predominance of smectite, are considered very limiting, mainly due to their shrink and swell properties that depend on the moisture content, making the management and trafficability very difficult, while the Argisols and Cambisols occupy an intermediate position in this context.

- Textural gradient: is characterized by a sandier surface horizon, with considerable clay accumulation in the subsurface horizon. This increment of clay in depth can be abrupt, when it occurs within a short vertical distance on the soil profile, or gradual, when it is more subtle. This fact implies on the reduction of soil permeability in depth and can contribute to the formation of perched water table, allowing for the lateral movement of solutions and solid particles, and making the soil susceptible to erosion (Streck et al., 2008; Costa et al., 2009).

- Structure: influences on the aeration, water storage, infiltration and soil erodibility (Companhia de Saneamento do Paraná, 1999; Streck et al., 2008; Pinto et al., 2015). According to Ferreira, Fernandes and Curi (1999), knowing the soil structure may help to understand its permeability and hence the ease that liquids move in the soil profile.

- Infiltration and natural drainage: provide indicatives on the permeability of the soil and the possibility of contaminating the water table. According to Pote et al. (2001), there may be contamination of groundwater when the infiltration rate in the soil is high. For that, one should consider that the other factors are similar.
- Type of surface horizon: the thickness of the surface horizon is directly related to soil volume with higher levels of organic matter in the profile, which contribute to adsorb the effluent. Greater thickness tends to increase the adsorption capacity and diminishes the contamination risk of the deepest layers of the profile and groundwater.

- Depth of the water table: it involves the growing risk of groundwater contamination (Streck et al., 2008) as this distance decreases in relation to the soil surface.

- Perched water table: in order to prevent contamination of subsurface waters, areas with shallow groundwater or groundwater above the surface should not be used for the disposal of waste due to the high risk of contamination.

- Distance from water bodies: one should avoid the final disposal of waste in the vicinity of water bodies to minimize the risk of contamination. According to Gomes and Martins (2003), areas that are subject to flooding are inappropriate for waste disposal, due to the possibility of contaminating the water courses by liquid generated in grounding systems.

- Relief: The local relief corresponds to the conformation of the ground surface, with variable slopes, such as flat $(0-3 \%$ slope), gently undulated (3$8 \%)$, undulated $(8-20 \%)$, strongly undulated $(20-45 \%)$, mountainous (45-75\%) and cliff (> 75\%) (Santos et al., 2013). In general, a steeper slope increases the risk of soil erosion and the movement of the applied waste towards the water bodies (Companhia de Saneamento do Paraná, 1999).

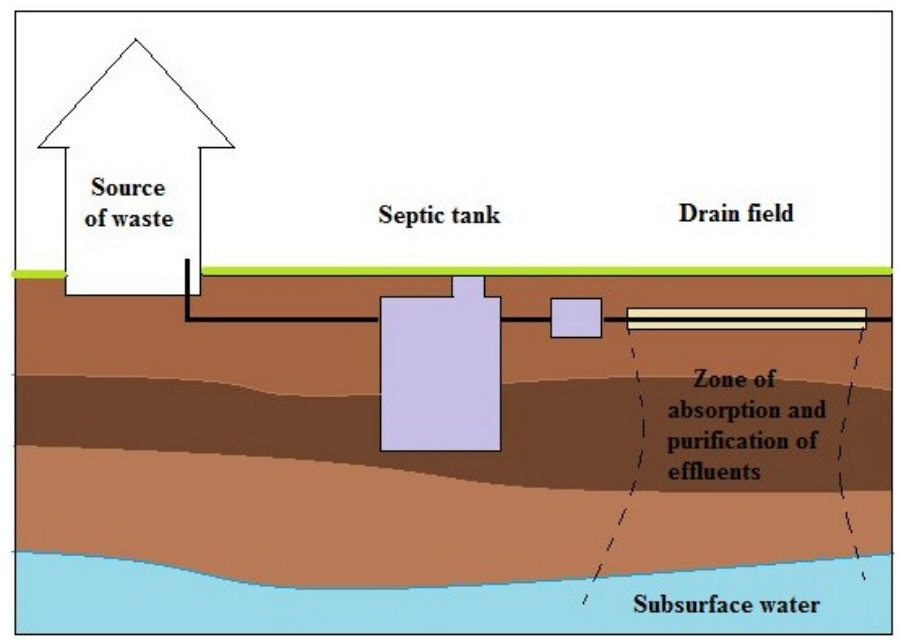

Figure 2: Scheme representing a septic system, which was the basis for defining the most appropriate soil and terrain attributes for its installation. 
- Rockiness and stoniness: the presence of boulders and/or rock outcrops can restrict the installation of sanitation systems and increase the lateral runoff of the deposited liquid waste.

- Flood risk: represents the risk of contamination by transport of pollutants to waterways.

From the main parameters, the criteria for defining the suitability of each site to the disposal of general waste are presented in Table 1. The occurrence of at least one attribute in less suitable classes is sufficient to reduce the suitability of the location.

\section{Suitability classes for septic systems installation}

From the attributes shown in Table 1, the following ones were selected for the installation of septic systems: soil depth, natural drainage, water table depth, relief and distance from the water bodies (Table 2). The latter was altered to suit the ABNT (1993) standard and, thus, distances greater or equal to $15 \mathrm{~m}$ were considered Adequate, whereas lesser than $15 \mathrm{~m}$ of distance are
Inadequate. However, these distances may be used only after approval by the responsible environmental agency. In the Adequate suitability class, mainly Latosols, Nitosols and Argisols occur (Streck et al., 2008). In the Regular suitability class mostly medium texture Latosols and Argisols occur. In the Restricted suitability class, Quartzarenic Neosols (excessively drained) and soils with imperfect drainage are predominant. Cambisols, in general, are included into the classes of Regular or Restricted suitability. In the Inadequate class, mainly Litholic Neosols (shallow soils) and soils with drainage problems (Gleysols and Histosols) are included. It is noteworthy to highlight that the soil classes here exemplified may have their suitability changed due to relief conditions. Furthermore, it is known that, within the same relief class, there are locales more suitable for septic systems installation than others. For instance, within the undulated relief class ( $8-20 \%$ slope), places with $9 \%$ slope would be more appropriate than those with $19 \%$ slope. For this reason, it is important to

Table 1: Guide table of the suitability classes for final waste disposal.

\begin{tabular}{|c|c|c|c|c|}
\hline \multirow{2}{*}{ Attribute } & \multicolumn{4}{|c|}{ Suitability classes } \\
\hline & Adequate & Regular & Restricted & Inadequate \\
\hline Soil depth (cm) & $>150$ & $>=100$ to 150 & $>=50$ to $<100$ & $<50$ \\
\hline Texture & Clayey (>35\% of clay) & $\begin{array}{c}\text { Medium ( } 15 \text { to } 35 \% \\
\text { of clay) }\end{array}$ & $\begin{array}{c}\text { Sandy }(<15 \% \text { of } \\
\text { clay) }\end{array}$ & $\begin{array}{c}\text { Sandy }(<15 \% \text { of } \\
\text { clay) }\end{array}$ \\
\hline Textural gradient & Without or gradual & $\begin{array}{c}\text { With gradient, if } \\
\text { abrupt in depth }>100 \\
\mathrm{~cm}\end{array}$ & $\begin{array}{c}\text { With gradient, if } \\
\text { abrupt in depth < } \\
100 \mathrm{~cm}\end{array}$ & $\begin{array}{c}\text { With gradient, if } \\
\text { abrupt in depth < } \\
50 \mathrm{~cm}\end{array}$ \\
\hline Natural drainage & $\begin{array}{l}\text { Well or moderately } \\
\text { drained }\end{array}$ & $\begin{array}{l}\text { Strongly or } \\
\text { accentuatedly } \\
\text { drained }\end{array}$ & $\begin{array}{l}\text { Imperfectly } \\
\text { or excessively } \\
\text { drained }\end{array}$ & $\begin{array}{l}\text { Poorly or very } \\
\text { poorly drained }\end{array}$ \\
\hline $\begin{array}{l}\text { Water table depth } \\
\qquad(\mathrm{cm})\end{array}$ & Absent or $>150$ & $\begin{array}{l}\text { Absent or from } 100 \\
\text { to } 150\end{array}$ & $<100$ & Superficial \\
\hline $\begin{array}{l}\text { Perched water } \\
\text { table }\end{array}$ & Absent & Absent & Present & Present \\
\hline $\begin{array}{l}\text { Distance from the } \\
\text { water bodies }^{1}(\mathrm{~m})\end{array}$ & $>200$ & $>200$ & $<200$ & $<200$ \\
\hline $\begin{array}{l}\text { Relief } \\
\text { (slope \%) }\end{array}$ & $\begin{array}{l}\text { Flat } \\
(0-3)\end{array}$ & $\begin{array}{l}\text { Gently undulated } \\
\qquad(3-8)\end{array}$ & $\begin{array}{l}\text { Undulated } \\
\quad(8-20)\end{array}$ & $\begin{array}{l}\text { Strongly undulated } \\
\text { or steeper }(>20)\end{array}$ \\
\hline Stoniness (\%) & $\begin{array}{c}\text { Not stony to } \\
\text { moderately stony }(<3)\end{array}$ & Stony (3 to 15 ) & $\begin{array}{c}\text { Very stony ( } 15 \text { a } \\
50)\end{array}$ & $\begin{array}{c}\text { Extremely stony } \\
\qquad(>50)\end{array}$ \\
\hline Rockiness (\%) & Not rocky $(<2)$ & $\begin{array}{l}\text { Slightly rocky } \\
\text { (2 to 10) }\end{array}$ & $\begin{array}{l}\text { Moderately rocky } \\
\text { (10 to } 25)\end{array}$ & $\begin{array}{l}\text { Rocky to extremely } \\
\text { rocky }(>25)\end{array}$ \\
\hline Flood risk & Null & Null & Rare & $\begin{array}{l}\text { Occasional to } \\
\text { frequent }\end{array}$ \\
\hline
\end{tabular}

${ }^{1}$ After environmental agency approval. 
perform an evaluation of land in the field at a more detailed scale than the proposed guidance attributes and values presented in Table 2, including engineering aspects if applicable.

This developed methodology was applied to the Marcela Creek watershed, considering the soil (Motta et al., 2001) and relief information. In relation to soil properties (Table 3), in general these did not offer great limitations on the installation of septic systems for most of the study area, because there is a predominance of deep, well-drained soils, besides having water table located deeper than $150 \mathrm{~cm}$, as recommended by ABNT (1997). Also, these soils do not contain stones, which could difficult the installation of septic systems, and they present very clayey texture and a moderate A horizon, which contributes to higher retention and purification of effluents disposed in both surface and subsurface soil. An exception to these conditions are the Gleysols, which have strong limitations due to their occurrence in lower places on the landscape, close to the water bodies, and hence presenting higher water table. Thus, terrain attributes, such as relief and distance from the water bodies were more relevant with regard to limitations on the installation of the sanitation system proposed for the study area, since they are more variable even within the same soil class (Figure 3).

Table 2: Soil properties and terrain characteristics considered relevant to allow for the installation of septic systems to promote efficient absorption and purification of effluents (Adapted from Kämpf et al. (2008) and Soil Survey Manual (1993)).

\begin{tabular}{|c|c|c|c|c|}
\hline \multirow{2}{*}{ Attribute } & \multicolumn{4}{|c|}{ Suitability classes for installation of septic systems } \\
\hline & Adequate & Regular & Restricted & Inadequate \\
\hline Soil depth (cm) & $>150$ & $>=100$ to 150 & $>=50$ to $<100$ & $<50$ \\
\hline Natural drainage & $\begin{array}{l}\text { Well or moderately } \\
\text { drained }\end{array}$ & $\begin{array}{l}\text { Strongly or } \\
\text { accentuatedly } \\
\text { drained }\end{array}$ & $\begin{array}{l}\text { Imperfectly } \\
\text { or excessively } \\
\text { drained }\end{array}$ & $\begin{array}{l}\text { Poorly or very poorly } \\
\text { drained }\end{array}$ \\
\hline $\begin{array}{l}\text { Water table depth } \\
(\mathrm{cm})\end{array}$ & $\begin{array}{l}\text { Absent or }>150 \\
\text { under the septic } \\
\text { system }\end{array}$ & $\begin{array}{l}\text { Absent or from } 100 \\
\text { to } 150 \text { under the } \\
\text { septic system }\end{array}$ & $\begin{array}{l}<100 \text { under the } \\
\text { septic system }\end{array}$ & Superficial \\
\hline $\begin{array}{c}\text { Distance from } \\
\text { water bodies }^{1}(\mathrm{~m})\end{array}$ & $>=15$ & $>=15$ & $>=15$ & $<15$ \\
\hline Relief (slope \%) & Flat $(0-3)$ & $\begin{array}{l}\text { Gently undulated } \\
\qquad(3-8)\end{array}$ & $\begin{array}{l}\text { Undulated } \\
\quad(8-20)\end{array}$ & $\begin{array}{l}\text { Strongly undulated or } \\
\text { steeper }(>20)\end{array}$ \\
\hline
\end{tabular}

Table 3: Properties of the soil classes found in Marcela Creek watershed ${ }^{1}$.

\begin{tabular}{|c|c|c|c|c|}
\hline \multirow{2}{*}{ Property } & \multicolumn{4}{|c|}{ Soil Class } \\
\hline & $\mathrm{HC}$ & RYL & $\mathrm{RL}$ & HG \\
\hline Soil depth (cm) & 155 & 240 & 200 & 120 \\
\hline Texture (clay \%) & $\begin{array}{l}\text { Very clayey } \\
\quad(>60)\end{array}$ & $\begin{array}{l}\text { Very clayey } \\
\quad(>60)\end{array}$ & $\begin{array}{l}\text { Very clayey } \\
\quad(>60)\end{array}$ & $\begin{array}{l}\text { Clayey } \\
(50)\end{array}$ \\
\hline Stoniness & Not stony & Not stony & Not stony & Not stony \\
\hline Parent material & $\begin{array}{l}\text { Product from the } \\
\text { alteration of pelitic } \\
\text { rocks interspersed with } \\
\text { quartzous material }\end{array}$ & $\begin{array}{l}\text { Product from } \\
\text { the alteration of } \\
\text { pelitic rocks }\end{array}$ & $\begin{array}{l}\text { Product from the } \\
\text { alteration of pelitic } \\
\text { rocks }\end{array}$ & $\begin{array}{l}\text { Quaternary } \\
\text { sediments }\end{array}$ \\
\hline $\begin{array}{l}\text { Natural drainage } \\
\text { Type of surface } \\
\text { horizon }\end{array}$ & $\begin{array}{l}\text { Well drained } \\
\text { Moderate A }\end{array}$ & $\begin{array}{l}\text { Well drained } \\
\text { Moderate A }\end{array}$ & $\begin{array}{l}\text { Accentuatedly } \\
\text { drained } \\
\text { Moderate A }\end{array}$ & $\begin{array}{c}\text { Poorly drained } \\
\text { Moderate A }\end{array}$ \\
\hline
\end{tabular}

${ }^{1}$ Adapted from Motta et al. (2001). 
Figure 4 illustrates the spatial distribution of suitability classes for determining the most likely places to receive septic tanks and drain fields.

From the total area of the watershed, 5.29\% were grouped as Adequate suitability, being, therefore, the most recommended for the installation of the proposed sanitation system. The Regular suitability sites account for $19.72 \%$ of the area, which is resultant from at least one of the following factors: soils with strong or accentuated drainage, gently undulate relief, or distance from the water

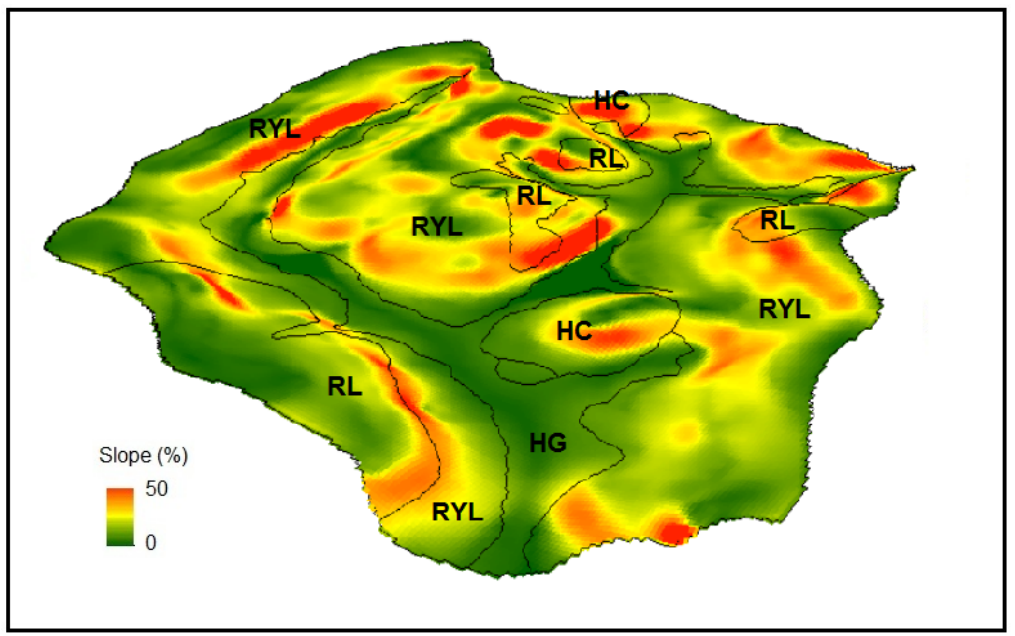

Figure 3: Distribution of slope in the Marcela Creed watershed related to soil classes.

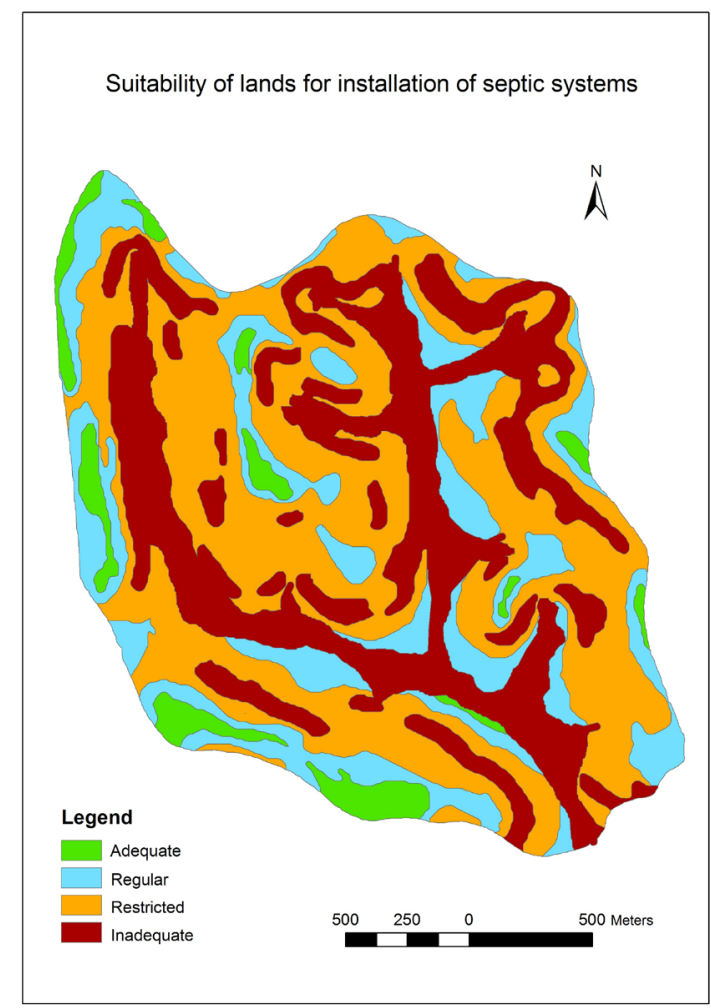

Figure 4: Suitability of lands for the installation of septic tanks and drain fields in Marcela Creek Watershed. 
bodies greater than $15 \mathrm{~m}$. The Restricted and Inadequate suitability sites make up, respectively, $41.99 \%$ and 33\% of the study area. These are sites that may have limitations related to drainage, ranging from imperfect to very poor, location in undulated or steeper relief, or even situated lesser than $15 \mathrm{~m}$ distant from the water bodies.

In the areas where Cambisols (HC) occur $(4.4 \%$ of the watershed), $0.11,1.14,1.61$ and 1.52 ha were confined into the Adequate, Regular, Restricted and Inadequate suitability classes, respectively (Table 4). Except for the areas classified as Adequate, such restrictions may be justified because these soils occur in relief ranging from gently undulated to strongly undulated (Table 5), increasing the risk of both soil and waste movement towards the water bodies and hence reducing its suitability to the installation of septic systems. The Red-Yellow Latosols (RYL) and the Red Latosols (RL), despite of being deep, they are present mainly in undulated areas, which results in lesser suitability than the ones on gentler topography. Nevertheless, they are soils that have the highest relative area with Adequate suitability for installation of septic systems, with $11.9 \%$ of RL areas and $5.4 \%$ of the areas of RYL, while HC have only $2.5 \%$ of their areas in that suitability class, and Gleysols (HG) are inadequate for this purpose.

Table 4: Area of the soil classes according to their suitability for installation of septic systems.

\begin{tabular}{cccc}
\hline Soil class & Suitability & Area (ha) & Area (\%) \\
\hline \multirow{3}{*}{ HC } & Adequate & 0.54 & 0.11 \\
& Regular & 5.54 & 1.14 \\
& Restricted & 7.8 & 1.61 \\
& Inadequate & 7.4 & 1.52 \\
HG & Inadequate & 75.33 & 15.5 \\
& Adequate & 17.53 & 3.61 \\
& Regular & 74.47 & 15.3 \\
& Restricted & 168.19 & 34.6 \\
& Inadequate & 65.04 & 13.4 \\
& Adequate & 7.63 & 1.57 \\
& Regular & 15.77 & 3.25 \\
RL & Restricted & 27.96 & 5.76 \\
& Inadequate & 12.51 & 2.57 \\
\hline Total & & 485.71 & 100 \\
\hline
\end{tabular}

Table 5: Area of the soil classes according to their relief phases.

\begin{tabular}{cccc}
\hline Soil class & Relief phase & Area (ha) & Area (\%) \\
\hline & Flat & 1.49 & 0.31 \\
& Gently undulated & 5.91 & 1.22 \\
& Undulated & 8.06 & 1.66 \\
$\mathrm{HC}$ & Strongly & & \\
& undulated & 5.82 & 1.20 \\
$\mathrm{HG}$ & Flat & 75.33 & 15.5 \\
& Flat & 20.43 & 4.21 \\
$\mathrm{RYL}$ & Gently undulated & 77.54 & 15.96 \\
& Undulated & 168.57 & 34.71 \\
& Strongly & & \\
& undulated & 58.69 & 12.08 \\
& Flat & 7.46 & 1.54 \\
& Gently undulated & 15.94 & 3.28 \\
& Undulated & 27.96 & 5.76 \\
RL & Strongly & 12.51 & 2.57 \\
\hline Total & undulated & 100 \\
\hline
\end{tabular}

The listed factors, both general for disposal of general waste (Table 1) and specific (Table 2) for the installation of septic systems, respectively, have only guiding character and do not replace the need for a local evaluation of land resistance to the impact of specific activities, including engineering aspects if applicable. Also, the authors do not know works involving this research line for southern Minas Gerais.

\section{CONCLUSIONS}

The proposed attributes and their values for determination of land suitability for waste disposal have the goal of helping and supporting decision makers about the most appropriate places for that, although more specific observations, adjustments and refinements are always encouraged.

In the studied pilot watershed, relief, proximity to water bodies, and natural soil drainage were the most limiting attributes for classification of land suitability for the installation of septic tanks and drain fields, because the majority of its soils, per se, contain adequate properties for such task. 


\section{ACNKNOWLEDGEMENTS}

The authors thank CNPq, CAPES and FAPEMIG for providing financial support for the development of this work.

\section{REFERENCES}

ABNT - Associação Brasileira de Normas Técnicas. NBR 13969: Tanques sépticos - unidades de tratamento complementar e disposição final dos efluentes líquidos - projeto, construção e operação. Rio de Janeiro: ABNT, 1997. 60p.

ABNT - Associação Brasileira de Normas Técnicas. NBR 7229: Projeto, construção e operação de sistemas de tanques sépticos: procedimentos. Rio de Janeiro: ABNT, 1993. 15p.

BITTON, G. Wastewater microbiology. 3 ed. New York: John Wiley \& Sons, 2005. 768p.

BOUMA, J. Subfarce applications of sewage effluente. In : BEATTY. M. T. et al. (ed). Planning the uses and managementof land. Madison, ASA-CSSA-SSSA. 1979. p.665-703.

COSTA, A. M. et al. Avaliação do risco de anoxia para o cultivo do eucalipto no Rio Grande do Sul utilizando-se levantamento de solos. Scientia Forestalis, 37:367-375, 2009.

COMPANHIA DE SANEAMENTO DO PARANÁ. Programa de pesquisa em saneamento básico. Uso e manejo do lodo de esgoto na agricultura. Curitiba: SANEPAR/PROSABFINEP, 1999. 98p.

EMPRESA BRASILEIRA DE PESQUISA AGROPECUÁRIA-EMBRAPA. Centro Nacional de Pesquisa de Solos. Sistema Brasileiro de Classificação de Solos. 3. ed. Rio de Janeiro, 2013. 353p.

FERREIRA, M. M.; FERNANDES, B.; CURI, N. Influência da mineralogia da fração argila nas propriedades físicas de Latossolos da região Sudeste do Brasil. Revista Brasileira de Ciência do Solo, 23:515-524, 1999.

GOMES, L. P.; MARTINS, F. B. Projeto, implantação e operação de aterros sustentáveis de resíduos sólidos urbanos para municípios de pequeno porte. In: CASTILHOS JUNIOR, A. B. Projeto, implantação e operação de aterros sustentáveis de resíduos sólidos urbanos para municípios de pequeno porte. Florianópolis:Editora Rima Artes e Textos, 2003. 288p.

INSTITUTO BRASILEIRO DE GEOGRAFIA E ESTATÍSTICA -IBGE -. PNAD: Pesquisa Nacional de Amostragem Domiciliar, ISSN 0101-6822. Rio de Janeiro, 32:1-134, 2012.

KÄMPF, N. et al. Metodologia para classificação de solos quanto à resistência a impactos ambientais decorrentes da disposição final de resíduos. FEPAM em Revista, 2:1117, 2008.

MOTTA, P. E. F. et al. Levantamento pedológico detalhado, erosão dos solos, uso atual e aptidão agrícola das terras de microbacia piloto na região sob influência do reservatório da hidrelétrica de Itutinga-MG. Lavras: UFLA/CEMIG, 2001. 51p.

PINTO, L. C. et al. Role of inceptisols in the hydrology of mountainous catchments in Southeastern Brazil. Journal of Hydrologic Engineering, 2015 Available at: <http://ascelibrary.org/doi/abs/10.1061/(ASCE)HE.19435584.0001275>. Accessed on: August, 21, 2015.

POTE, D. H. et al. Water-quality effects of infiltration rate and manure application rate for soils receiving swine manure. Journal of Soil and Water Conservation, 56:32-37, 2001.

RESENDE, M. et al. Mineralogia de Solos Brasileiros Interpretações e Aplicações. 2. ed. Lavras: EDITORA UFLA, 2011. $201 p$.

SANTOS, R. D. dos et al. Manual de descrição e coleta de solo no campo. 6. ed. Viçosa: SBCS, 2013. 100p.

SILVA, F. A. et al. Influência da temperatura, umidade e profundidade do solo na persistência do diurom. Química Nova, 33:1457-1463, 2010.

SOIL SURVEY STAFF. Soil Survey Manual. USDA Handbook No. 18. Washington: US Government Printing Office, 1993. 437p.

STRECK, E. V. et al. Solos do Rio Grande do Sul. 2. ed. Porto Alegre: EMATER/RS-ASCAR, 2008. 222p.

VON SPERLING, M. Introdução à qualidade das águas e ao tratamento de esgotos. 2. ed. Belo Horizonte: UFMG,1996. 246p. 